\begin{tabular}{|c|}
\hline  \\
\hline
\end{tabular}

Received date 29.06.2019

Accepted date 31.07.2019

Published date 31.08.2019
UDC 621.92:669.017

DOI: $10.15587 / 1729-4061.2019 .176825$

\section{INCREASING EFFICIENCY OF PLASMA HARDENING BY LOCAL COOLING OF SURFACE BY AIR WITH NEGATIVE TEMPERATURE}

\author{
A. B e spalova \\ $\mathrm{PhD}$, Associate Professor* \\ V. Le bede v \\ Doctor of Technical Sciences, Professor** \\ E-mail: wlebedev29@rambler.ru \\ o. Frolenkova \\ Assistant** \\ E-mail: 5olgavf@gmail.com \\ A. Kn ysh \\ $\mathrm{PhD}$, Associate Professor* \\ E-mail dop.od@ukr.net \\ O. Dashkovskaya \\ $\mathrm{PhD}$, Associate Professor* \\ E-mail dop.od@ukr.net \\ O. F a y z ulina \\ $\mathrm{PhD}$, Associate Professor* \\ *Department of Construction and Labor Protection \\ Odessa State Academy of \\ Civil Engineering and Architecture \\ Didrihsona str., 4, Odessa, Ukraine, 65029 \\ **Department of Materials and Materials Technology \\ Odessa National Polytechnic University \\ Shevchenka ave., 1, Odessa, Ukraine, 65044
}

Copyright (C) 2019, A. Bespalova, V. Lebedev,

O. Frolenkova, A. Knysh, O. Dashkovskaya, O. Fayzulina This is an open access article under the CC BY license (http://creativecommons.org/licenses/by/4.0)

\section{Introduction}

In modern construction, a large number of machines and mechanisms are used, the parts of which work under significant loads, which often leads to significant wear of their working surfaces and failure of parts. It is economically feasible to restore such parts, for example, by surfacing. The resulting new surfaces must be hardened by heat treatment to obtain the necessary mechanical characteristics.

Hardening of steels by heating with concentrated energy flows, in particular, plasma hardening, by analogy with other types of hardening, consists in the formation of an austenitic structure during heating and its further transformation into martensite at the cooling stage [1,2]. In this case, the thermal energy is greater than the energy necessary for the restructuring of the crystal lattice, and the restructuring itself occurs at a certain finite rate. Therefore, the transformation is carried out in the temperature range from $A c_{1}$ to $A c_{3}$, that is, the end of the austenitic transformation shifts to the region of higher temperatures (Fig. 1).

Due to the high heating rate, the diffusion processes of restructuring of the lattice of the body-centered cube of proeutectoid ferrite into the lattice of the face-centered austenite cube may not end on the GS line of the $\mathrm{Fe}-\mathrm{Fe}_{3} \mathrm{C}$ diagram and shift to the region of higher temperatures (region 2). Microfusion of the cementite boundary from austenite can also occur (region 3) [1].

As a result, a structure is formed whose features are determined by the degree of completion of the austenitization process. At a sufficiently high heating temperature or with relatively long exposure time, the formation of uniform austenite is possible. A decrease in the heating temperature 
and exposure time as a result of increasing critical points and a slowdown in the homogenization process lead to greater heterogeneity of austenite in steel, especially with respect to carbon. In addition to austenite, under these conditions at high temperature there may exist carbides that have not dissolved. Plasma hardening cooling is characterized by high speeds. Thus, the cooling rate during plasma hardening varies from 104 to $105^{\circ} \mathrm{C} / \mathrm{s}$, which is much higher than the critical cooling rate during hardening, resulting in the austenite-martensite diffusionless transformation.

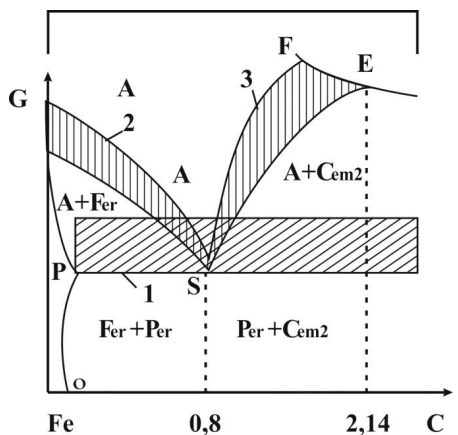

Fig. 1. Section of the $\mathrm{Fe}-\mathrm{Fe} 3 \mathrm{C}$ diagram with structural transformations during high-speed heating [1]:

1 - boundary of the ferrite phase; 2,3 - boundaries of the austenitic phase

It should be noted that in order for austenite to become martensite almost completely, it is necessary that the temperature passes completely through the so-called martensitic temperature interval between the start $M_{s}$ and finish $M_{f}$ points of the martensitic transformation. The temperature of these points substantially depends on the carbon content in steel (Fig. 2) [2].

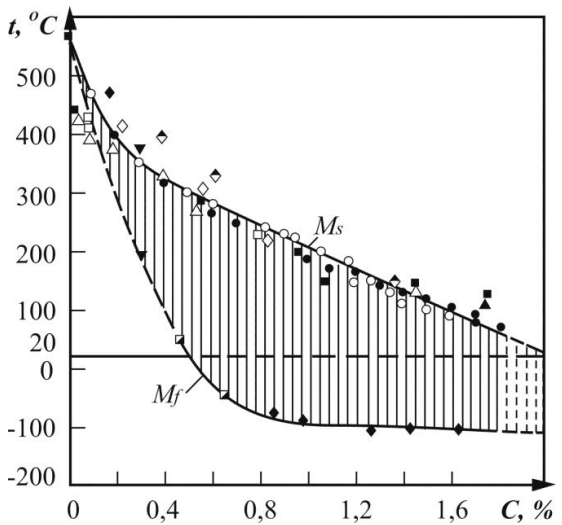

Fig. 2. Temperature of $M_{s}$ and $M_{f}$ points depending on carbon content in steel [2]

Surface plasma hardening is carried out in a workshop where the temperature is maintained at $+20{ }^{\circ} \mathrm{C}$. Thus, the complete "austenite - martensite" transformation is possible only for steels with a carbon content of not more than $0.5 \%$, that is, not even for all hypoeutectoid steels. If surface plasma hardening is carried out for steels with high carbon content, the conversion of austenite to martensite will be incomplete. The hardened layer will contain a certain amount of residual austenite, and the greater, the greater the carbon content in the steel.
Therefore, to expand the range of plasma hardening of steels, it is necessary to locally lower the surface temperature to negative temperatures, which will make it possible to fully harden steels with a carbon content corresponding to eutectoid and hypereutectoid steels. Therefore, studies aimed at expanding the capabilities of full plasma hardening of eutectoid and hypereutectoid steels are relevant.

\section{Literature review and problem statement}

The literature devoted to plasma hardening, for example, [1,3-5] does not contain direct indications of the effect of the martensitic interval on the phase-structural composition of the hardened layer.

In [3], nitriding followed by plasma hardening, microhardness, and wear resistance are considered in detail. The mechanical characteristics of the material are investigated. However, the work was done only for steel containing $0.5 \% \mathrm{C}$. This makes it impossible to compare the obtained characteristics with the characteristics of steels with higher carbon content, when the $M_{f}$ point shifts to the region of negative temperatures.

In [4], the effect of plasma flows generated by a three-electrode and multi-electrode plasmatron on the surface is studied. It is concluded that the use of multi-electrode plasmatrons is preferable to obtain a higher hardness of the hardened surface. The temperatures of the martensitic interval are not considered.

In [5], the influence of the oscillation regime on the surface quality when using a low-temperature plasma is considered. The most favorable modes are shown and conclusions are drawn about the need for further monitoring of the process. The effect of carbon content on the quality of the hardened layer is not considered.

In [6], the issue of plasma carburizing of hardened and aging alloys of the $\mathrm{Cu}-\mathrm{Ti}$ system is considered. The research results cannot be applied to steels.

The effect of low-temperature plasma on the surface of austenitic stainless steel is considered in [7]. It is shown that, by changing the plasma exposure regimes, it is possible to obtain surface structures with an expanded austenite crystal lattice. The results of the work also cannot be applied to the issue under consideration.

The work [8] considers the issues of low-temperature plasma nitriding of martensitic and austenitic stainless steels. It is shown that an increase in the characteristics of wear resistance to a large extent depends on the modes without sacrificing corrosion resistance.

The issue of plasma hardening of rail steel is considered in [9]. The structural composition of the treated surface layer is shown. It is shown that the wear resistance of the treated surface is significantly increased. The paper does not indicate the carbon content in the steel under study, however, based on the standard chemical composition, it can be assumed that the carbon content is $0.7-0.8 \%$. The authors indicate that residual austenite is present in the structure, which indirectly indicates that the $M_{f}$ point is in the region of negative temperatures. The paper indicates that the wear resistance of the rail is significantly increased.

In [10], plasma hardening of hypereutectoid steels is considered. We consider steels with a carbon content of 1 and $1.2 \%$. As can be seen from Fig. 2, the $M_{f}$ point for these 
steels is in the region of $-80{ }^{\circ} \mathrm{C}$. The paper has somewhat conflicting data, namely, with the same heat input, the same amount of martensite and residual austenite is shown. The data available in the work must be checked.

In [11], high-speed plasma hardening of all types of passenger, freight, and locomotive wheelsets is considered. Tests show that in all cases, the degree of wear of the wheelset flanges after plasma hardening is significantly lower (2.53.0 times) than the flanges after standard heat treatment. The paper gives an example of eutectoid steel hardening. It is shown that the metal structure after plasma hardening consists of 50/50 \% martensite and troostite. However, the surface heating temperature is not given in the work. It can be assumed that the heating exceeded the temperature of $727^{\circ} \mathrm{C}$ to the zone of pure austenite according to the $\mathrm{Fe}$ $\mathrm{Fe}_{3} \mathrm{C}$ diagram, which, upon cooling, turned into martensite by $50 \%$. The data obtained in this work are not associated with the temperature martensitic interval.

As can be seen from the literature review, no data were found regarding the dependence of the structure of steel formed by plasma hardening on the hardening temperature, carbon content and martensitic interval, i. e., the position of the $M_{s}$ and $\mathrm{M}_{\mathrm{f}}$ points. There is also no evidence of a local decrease in temperature during plasma hardening.

\section{The aim and objectives of the study}

The aim of the study is to create conditions for the use of all or most of the martensitic transformation interval during plasma hardening due to the immediate cooling of the plasma-heated surface by air with a negative temperature.

To achieve this goal, the following objectives are set:

- to heat the surface of the hardened steel with a plasma beam to temperatures of $750{ }^{\circ} \mathrm{C}$ and $900{ }^{\circ} \mathrm{C}$, controlling the temperature according to the procedure [12];

- to obtain a directed jet of air cooled to a negative temperature through the use of the Ranque-Hilsch tube, directing a stream of cooled air after the plasma jet;

- to carry out hardening of hypoeutectoid, eutectoid and hypereutectoid steels without cooling with a stream of cold air and with cooling, comparing the obtained structures and hardness of the hardened layer.

\section{Research methods and materials}

The surface of the sample was heated by the plasma flow to a temperature of $750{ }^{\circ} \mathrm{C}$ and $900{ }^{\circ} \mathrm{C}$ (PMS 201 plasmatron), and the temperature was controlled by the method of [12]. The temperature was changed by the plasma torch current and by changing the velocity of the plasma flow spot moving along the sample surface. The temperature of $750{ }^{\circ} \mathrm{C}$ below the GSE line in the iron-carbon diagram [2] in the state diagram of $\mathrm{Fe}-\mathrm{Fe}_{3} \mathrm{C}$ [2] corresponds to the temperature of incomplete hardening for hypoeutectoid and eutectoid steels. The temperature of $900{ }^{\circ} \mathrm{C}$ above the GSE line corresponds to a full hardening temperature for the same steels. The experiments were carried out on steels $45(0.45 \% \mathrm{C})$, U8 $(0.8 \% \mathrm{C})$ and U10 (1 \% C).

The microstructures of the samples were made in accordance with the source [14].

The study of the structures was carried out on a MIM-7 microscope with a video camera and with the image dis- played on the screen. The approximate quantitative composition of austenite, martensite, and associated structures was determined by the areas on the screen.

The hardness of the hardened samples was measured on a Rockwell hardness gage on the HRC scale.

Electron microscopy was not used, since only structures, i. e. grains and grain boundaries, were studied, while electron microscopy was used for studies at the level of fragments and blocks.

The surface heated by the plasma beam was cooled by air cooled to a temperature of $-40{ }^{\circ} \mathrm{C}$, leaving the "cold shoulder" of the Ranque-Hilsch tube. The Ranque-Hilsch tube is a cheap and small-sized device that, when connected to the workshop's pneumatic system, produces a temperature air stream of $-40{ }^{\circ} \mathrm{C}$, which in most cases covers half the martensitic interval in the region of negative temperatures. The use of other cooling media, such as liquid nitrogen or solid carbon dioxide, complicates and increases the cost of the hardening process.

For use in a production environment, such a temperature reduction is simple and minimally energy-consuming.

The vortex effect of the tube (Ranque-Hilsch effect) is the effect of dividing a gas or liquid into two fractions when twisting in a cylindrical or conical chamber. A swirling flow with a high temperature $\left(+110^{\circ} \mathrm{C}\right)$ is formed on the periphery, and a cooled flow swirling in the opposite direction $\left(-40{ }^{\circ} \mathrm{C}\right)$ is formed in the center (Fig. 3) [13]. An explanation of this effect is given in the sources [13,14].

The tube is connected to the pneumatic system of the workshop (pressure $6 \mathrm{~kg} / \mathrm{cm}^{2}$ ), as a result of which cold and hot air can be obtained without any additional devices.

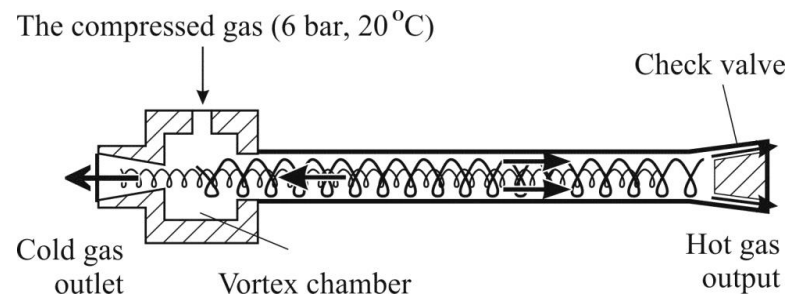

Fig. 3. Ranque-Hilsch tube [14]

The stream of cold air is sent directly to the surface of the part after the plasma beam, cooling this surface immediately after heating it with plasma to an austenitic structure. As a result of immediate cooling, the temperature range of the $M_{f}$ point expands, resulting in complete martensitic transformation for eutectoid and a certain number of hypereutectoid steels. The scheme of the device for plasma surface hardening using the Ranque-Hilsch tube is shown in Fig. 4.

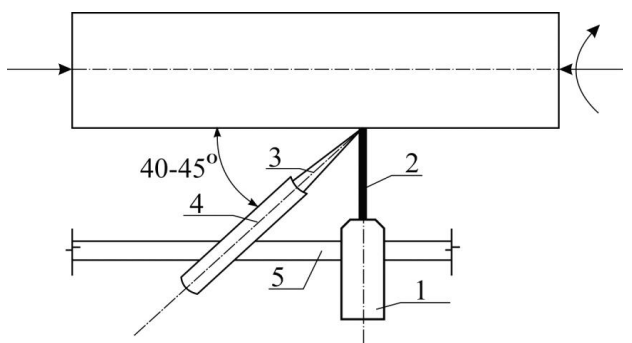

Fig. 4. Scheme of plasma surface hardening using the Ranque-Hilsch tube for local cooling: 1 - plasma torch; 2 - plasma beam; 3 - stream of cold air; 4 -Ranque-Hilsch tube; 5 - base plate 
The device shown in Fig. 7 is easy to assemble in a mechanical assembly shop and can be mounted on the turning slide.

\section{Plasma hardening studies without local surface cooling}

The studies compared the structures after conventional plasma hardening and after plasma hardening with local cooling of the surface (task 3 ). The initial structure corresponded to the structure of the deposited layer after normalization in accordance with the $\mathrm{Fe}-\mathrm{Fe}_{3} \mathrm{C}$ diagram depending on the carbon content [2].

Plasma hardening of steel 45 . Temperature $750{ }^{\circ} \mathrm{C}$. $M_{s}=330{ }^{\circ} \mathrm{C} ; M_{f}=80^{\circ} \mathrm{C}$. When cooling, the temperature completely passes the martensitic interval. The austenite formed upon heating completely turns into martensite. The structure contains about $35 \%$ ferrite (Fig. 3). Hardness after hardening is HRc64.

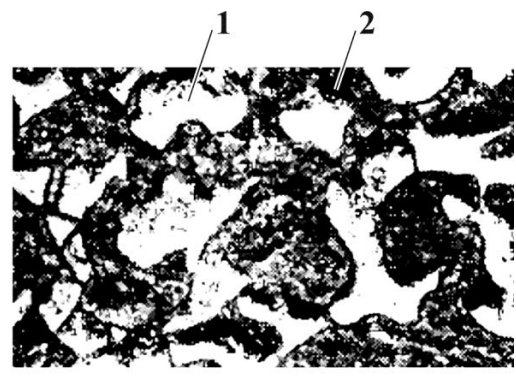

$0 \quad 8001600$

Fig. 5. Plasma hardening of steel 45 . Temperature $750{ }^{\circ} \mathrm{C}$. $M_{s}=330{ }^{\circ} \mathrm{C} ; M_{f}=80^{\circ} \mathrm{C}$. Structure: $1-$ ferrite, $2-$ martensite. GSP heating temperature. Magnification $\times 400$

Plasma hardening of U8 steel. (Eutectoid steel) Temperature $750{ }^{\circ} \mathrm{C} . M_{s}=+260{ }^{\circ} \mathrm{C} ; M_{f}=-60{ }^{\circ} \mathrm{C}$. When cooled to the workshop temperature $\left(+20{ }^{\circ} \mathrm{C}\right)$, the temperature does not reach the value $M_{f}=-60{ }^{\circ} \mathrm{C}$. Residual austenite is present in the structure (Fig. 4). HRc 62.

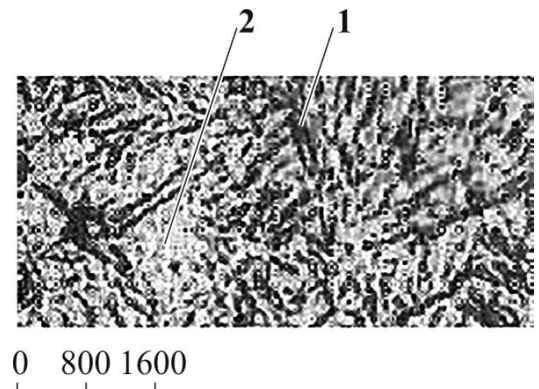

Fig. 6. Plasma hardening of U8 steel. Temperature $750{ }^{\circ} \mathrm{C}$. $M_{s}=+260{ }^{\circ} \mathrm{C} ; M_{f}=-60{ }^{\circ} \mathrm{C}$. Structure: 1 - martensite,

$2-$ residual austenite. Magnification $\times 400$

Plasma hardening of U10 steel. (Hypereutectoid steel) Temperature $750{ }^{\circ} \mathrm{C} . M_{s}=+180{ }^{\circ} \mathrm{C} ; M_{f}=-80{ }^{\circ} \mathrm{C}$. When cooled to a workshop temperature $\left(+20^{\circ} \mathrm{C}\right)$, the temperature does not pass the martensitic interval by $100{ }^{\circ} \mathrm{C}$. The structure contains residual austenite and secondary cementite. (Fig. 5). HRc 60-62.



Fig. 7. Plasma hardening of U10 steel. Temperature $750{ }^{\circ} \mathrm{C}$. $M_{s}=+180{ }^{\circ} \mathrm{C} ; M_{f}=-80{ }^{\circ} \mathrm{C}$. Residual austenite (1) and secondary cementite (3) are present in the structure. Main structure - martensite (2). Magnification $\times 400$

6. Conducting plasma hardening studies with local surface cooling

Plasma hardening with local surface cooling from a temperature of $900{ }^{\circ} \mathrm{C}$. This temperature corresponds to the temperature of full hardening for all considered steels.

In the present work, for the local reduction of locally after heating with plasma, the surface is cooled directly to a temperature of $-40{ }^{\circ} \mathrm{C}$ using the Ranque-Hilsch tube, which is described above.

The stream of cold air is sent directly to the surface of the part after the plasma beam, cooling this surface immediately after heating it with plasma to an austenitic structure. As a result of immediate cooling, the temperature range of the $M_{f}$ point expands, resulting in complete martensitic transformation for eutectoid and a certain number of hypereutectoid steels.

During plasma hardening of steel 45 from a temperature of $900{ }^{\circ} \mathrm{C}$ using the Ranque-Hilsch tube, there is practically no residual austenite in the structure. The hardness of the sample HRC 64. The microsection is identical to Fig. 4.

When hardening U8 steel with local cooling, residual austenite is detected in an insignificant amount (5-10\%) (Fig. 8).

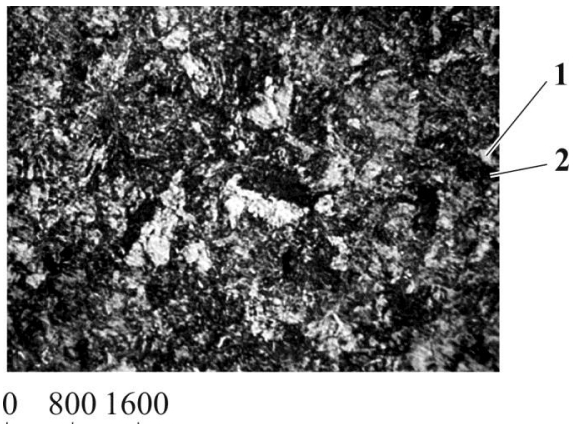

Fig. 8. Steel U8. Plasma hardening of U8 steel with local cooling. Hardening temperature $900{ }^{\circ} \mathrm{C} . M_{s}=+260{ }^{\circ} \mathrm{C}$; $M_{f}=-60{ }^{\circ} \mathrm{C}$. The structure has a small amount of residual austenite (1). The main structure is martensite (2) HRC 64. Magnification $\times 400$

During hardening of U10 steel, the amount of residual austenite is approximately $15-20 \%$. There is some secondary cementite. 


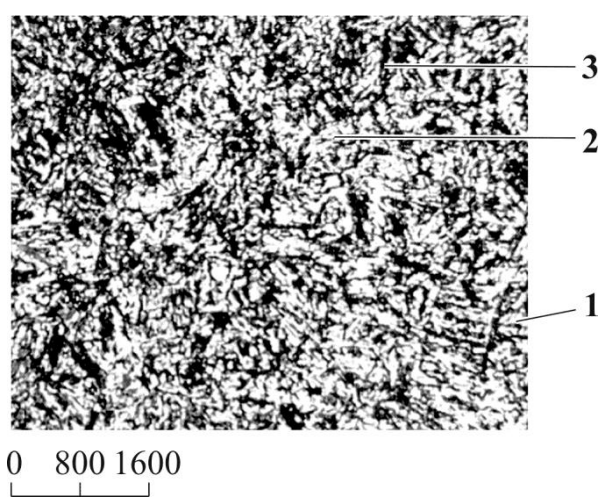

Fig. 9. Plasma hardening of $U 10$ steel with local cooling. Hardening temperature $900{ }^{\circ} \mathrm{C} . M_{s}=+180^{\circ} \mathrm{C} ; M_{f}=-80^{\circ} \mathrm{C}$.

Residual austenite (1) and secondary cementite (2) are present in the structure. The main structure is martensite (3) HRc 62-64. Magnification $\times 400$

\section{Discussion of the results of the study of the} effectiveness of plasma hardening with local cooling

The work performed showed that local cooling to negative temperatures during plasma hardening in the workshop is possible due to the use of the Ranque-Hilsch tube (Fig. 3,4). Such cooling allows the surface temperature during cooling to reach the martensitic points $M_{f}$, which are in the region of negative temperatures. As a result, the cooling temperature during hardening of eutectoid and hypereutectoid steels either completely passes the martensitic temperature range, or most of it. This circumstance makes it possible to obtain a minimum amount of residual austenite during plasma hardening of these steels and makes low tempering unnecessary for the decomposition of residual austenite (Fig. 8, 9).

The peculiarity of the method used is that it allows you to cool local regions of the part immediately after the passage of the plasma beam during surface hardening.

The disadvantage of this cooling method is that it provides a decrease in surface temperature only to $-40{ }^{\circ} \mathrm{C}$, while the $M_{f}$ point of high alloy steels can be in the range of -80 ; $-100{ }^{\circ} \mathrm{C}$.

The development of this method may consist in the fact that liquid nitrogen can be used to lower the temperature. However, this complicates and increases the cost of the hardening process; therefore, this method can be recommended only for highly responsible parts.

\section{Conclusions}

1. It was found that with local cooling of the surface of the part during plasma hardening, almost complete austenite-martensite transformation is observed in eutectoid steels. The content of residual austenite is not more than $10 \%$. With local cooling of the surface of the hypereutectoid steel part, during plasma hardening, a significant decrease in the amount of residual austenite in the hardened structure is observed.

2. The use of local cooling during plasma hardening through the use of the Ranque-Hilsch tube is easily accessible. This makes low tempering unnecessary for the decomposition of residual austenite.

3. The hardness of the plasma-hardened surface with local cooling due to the use of the Ranque-Hilsch tube is stable in the range of 62-64 HRC, which corresponds to the hardness of tempered martensite.

\section{References}

1. Lashchenko, G. I. (2003). Plazmennoe uprochnenie i napylenie. Kyiv: Ekotehnologiya, 64.

2. Gulyaev, A. P. (2010). Materialovedenie. Moscow: Avangard.

3. Yan, M. F., Chen, B. F., Li, B. (2018). Microstructure and mechanical properties from an attractive combination of plasma nitriding and secondary hardening of M50 steel. Applied Surface Science, 455, 1-7. doi: https://doi.org/10.1016/j.apsusc. 2018.04.213

4. Xiang, Y., Yu, D., Li, Q., Peng, H., Cao, X., Yao, J. (2015). Effects of thermal plasma jet heat flux characteristics on surface hardening. Journal of Materials Processing Technology, 226, 238-246. doi: https://doi.org/10.1016/j.jmatprotec.2015.07.022

5. Martynov, V., Brzhozovsky, B., Zinina, E., Yankin, I., Susskiy, A. (2017). Fluctuations in the Process Plant as a Quality Assessment Criterion of Low-temperature Plasma Hardening Process. Procedia Engineering, 176, 451-460. doi: https://doi.org/10.1016/ j.proeng.2017.02.344

6. Semboshi, S., Iwase, A., Takasugi, T. (2015). Surface hardening of age-hardenable $\mathrm{Cu}-\mathrm{Ti}$ alloy by plasma carburization. Surface and Coatings Technology, 283, 262-267. doi: https://doi.org/10.1016/j.surfcoat.2015.11.003

7. Lebrun, J. P. (2015). Plasma-assisted processes for surface hardening of stainless steel. Thermochemical Surface Engineering of Steels, 615-632. doi: https://doi.org/10.1533/9780857096524.4.615

8. Esfandiari, M., Dong, H. (2006). Plasma surface engineering of precipitation hardening stainless steels. Surface Engineering, 22 (2), 86-92. doi: https://doi.org/10.1179/174329406x98368

9. Xiang, Y., Yu, D., Cao, X., Liu, Y., Yao, J. (2017). Effects of thermal plasma surface hardening on wear and damage properties of rail steel. Proceedings of the Institution of Mechanical Engineers, Part J: Journal of Engineering Tribology, 232 (7), 787-796. doi: https://doi.org/10.1177/1350650117729073

10. Safonov, E. N., Mironova, M. V. (2018). Plasma hardening hypereutectoid steel. IOP Conference Series: Materials Science and Engineering, 411, 012069. doi: https://doi.org/10.1088/1757-899x/411/1/012069 
11. Petrov, S. V., Saakov, A. G. (2002). Technology and equipment for plasma surface hardening of heavy-duty parts. Materials and Manufacturing Processes, 17 (3), 363-378. doi: https://doi.org/10.1081/amp-120005382

12. Nechaev, V. P., Ryazantsev, A. A. (2012). Issledovanie, razrabotka, obosnovanie vozmozhnostey povysheniya nadezhnosti raboty krupnomodul'nyh shesteren putem plazmennogo uprochneniya ih poverhnostey. Prohresyvni tekhnolohiyi i systemy mashynobuduvannia, 43, 227-232.

13. Horobryh, M. A., Klement'ev, V. A. (2012). Vihrevoy ehffekt Ranka-Hilsha. Vihrevaya truba. Molodoy ucheniy, 6, 54-55.

14. Korkodinov, I. A., Khurmatullin, O. G. (2012). The Application of Ranque - Hilsh Effect. Vestnik permskogo natsional'nogo issledovatel'skogo politehnicheskogo universiteta. Mashinostroenie, materialovedenie, 14 (4), 42-54.

15. Metodika prigotovleniya mikroshlifa. Available at: https://infourok.ru/laboratornaya-rabota-metodika-prigotovleniya-mikroshlifa-852852.html

16. Mikroskop MIM-7 metallograficheskiy. Available at: https://svetlovodsk.flagma.ua/mikroskop-mim-7-metallograficheskiyo4107365.html

17. Pribor dlya izmereniya tverdosti po metodu Rokvella TR 5006M. Available at: http://ukrsk.com.ua/pribor_tr_5006m.html 